\title{
Antitumour Efficacy of Piper tuberculatum and Piplartine Based on the Hollow Fiber Assay
}

Authors

Affiliations
Daniel P. Bezerra ${ }^{1}$, Paulo Michel P. Ferreira ${ }^{2}$, Camila Maria L. Machado ${ }^{3}$, Nayara C. de Aquino ${ }^{4}$, Edilberto R. Silveira ${ }^{4}$, Roger Chammas ${ }^{3}$, Claudia Pessoa ${ }^{5,6}$

The affiliations are listed at the end of the article
Key words

- Piper tuberculatum

- Piperaceae

- Piplartine

- antitumour

hollow fiber

\section{Abstract}

$\nabla$

Piper tuberculatum, popularly known in Brazil as "jaborandi falso" and "pimenta darta", is widely used in folk medicine for the treatment of several diseases. In this study, the in vivo hollow fiber assay was used to investigate the antitumour efficacy of the crude extract and piplartine obtained from $P$. tuberculatum roots. Human glioblastoma (SF-295) and colon carcinoma (HCT-8) cell lines were used. In vitro cytotoxicity was assayed by the MTT assay. In the hollow fiber assay, nude mice implanted with tumour cells in hollow fibers were treated for four consecutive days via the intraperitoneal route, and tumour cell populations were assessed by the MTT assay. Both the crude extract and piplartine displayed cytotoxicity. In the hollow fiber assay, tumour growth inhibition rates were $24.6-54.8 \%$ for the crude extract and $33.7-62.2 \%$ for piplartine. No signal of toxicity was noticed. In conclusion, the crude extract and piplartine obtained from $P$. tuberculatum roots displayed in vitro and in vivo anticancer efficacy.

\section{Introduction}

Bibliography

Dol http://dx.doi.org/

10.1055/s-0034-1383363

Planta Med 2015; 81: 15-19

(c) Georg Thieme Verlag KG

Stuttgart · New York

ISSN 0032-0943

\section{Correspondence}

\section{Pessoa}

Universidade Federal do Ceará Faculdade de Medicina

Departamento de Fisiologia e

Farmacologia

Av. Cel. Nunes de Melo, 1127 -

Rodolfo Teófilo

60430-270 Fortaleza - CE

Brazil

Phone: + 558533668255

Fax: + 558533668333

c_pessoa@yahoo.com

\section{Correspondence}

D.P. Bezerra

Fundação Oswaldo Cruz Centro de Pesquisas Gonçalo Moniz

Rua Waldemar Falcão, 121

Candeal

40296-710 Salvador - Ba

Brazil

Phone: + 557131762272

Fax: + 557131762272

danielpbezerra@gmail.com
Piper tuberculatum Jacq. is a species of pepper belonging to the Piperaceae family. It is popularly known in Brazil as "jaborandi falso" and "pimenta darta", and is widely used in folk medicine as an analgesic, sedative, antidote for snakebites, and treatment for digestive disorders [1,2]. Some pharmacological studies have reported larvicidal [3], molluscicidal [4], and gastroprotective [5] activities of extracts and fractions of $P$. tuberculatum. Phytochemical analyses of $P$. tuberculatum extracts have identified the presence of a variety of amides with different biological activities [1,2, 5-7]. Among these compounds, piplartine, also known as piperlongumine, is the most commonly studied.

The reported pharmacological activities of piplartine include cytotoxic [6,8-10], antitumour [10$12]$, genotoxic $[13,14]$, antiangiogenic [10], antimetastatic [10], anxiolytic [2], antidepressant [2], leishmanicidal [15], and trypanocidal [16] activities. Among the multiple pharmacological effects of piplartine, its anticancer property is the most promising [17]. In this study, the in vivo hollow fiber assay (HFA) was used to investigate the antitumour efficacy of the crude extract and piplartine obtained from $P$. tuberculatum roots.

\section{Results and Discussion}

$\nabla$

The present work investigated the in vivo antitumour efficacy of the crude extract and piplartine obtained from $P$. tuberculatum roots through the in vivo HFA. The HFA is a standard in vivo model that allows simultaneous evaluation of multiple cell lines. It was developed by Hollingshead et al. [18] as a model with a shorter evaluation time and a reduced compound requirement compared to traditional xenograft models. The in vitro cytotoxic effect was also assayed by the 3-(4,5-dimethyl-2-thiazolyl)-2,5-diphenyl-2H-tetrazolium bromide (MTT) assay. As cited above, the in vitro cytotoxic effect of piplartine has been previously examined [6,8-10]; however, in vitro cytotoxicity of the crude extract obtained from $P$. $t u$ berculatum roots has never been investigated. In addition, the in vivo antitumour efficacy of the crude extract and piplartine obtained from $P$. $t u$ berculatum roots was, in this study, evaluated through the in vivo HFA for the first time.

The extraction of $P$. tuberculatum roots resulted in a crude extract and piplartine. Fig. 1 shows representative chromatograms from HPLC analysis of the crude extract and piplartine obtained from $P$. tuberculatum. Piplartine is the main compound found in the crude extract. 


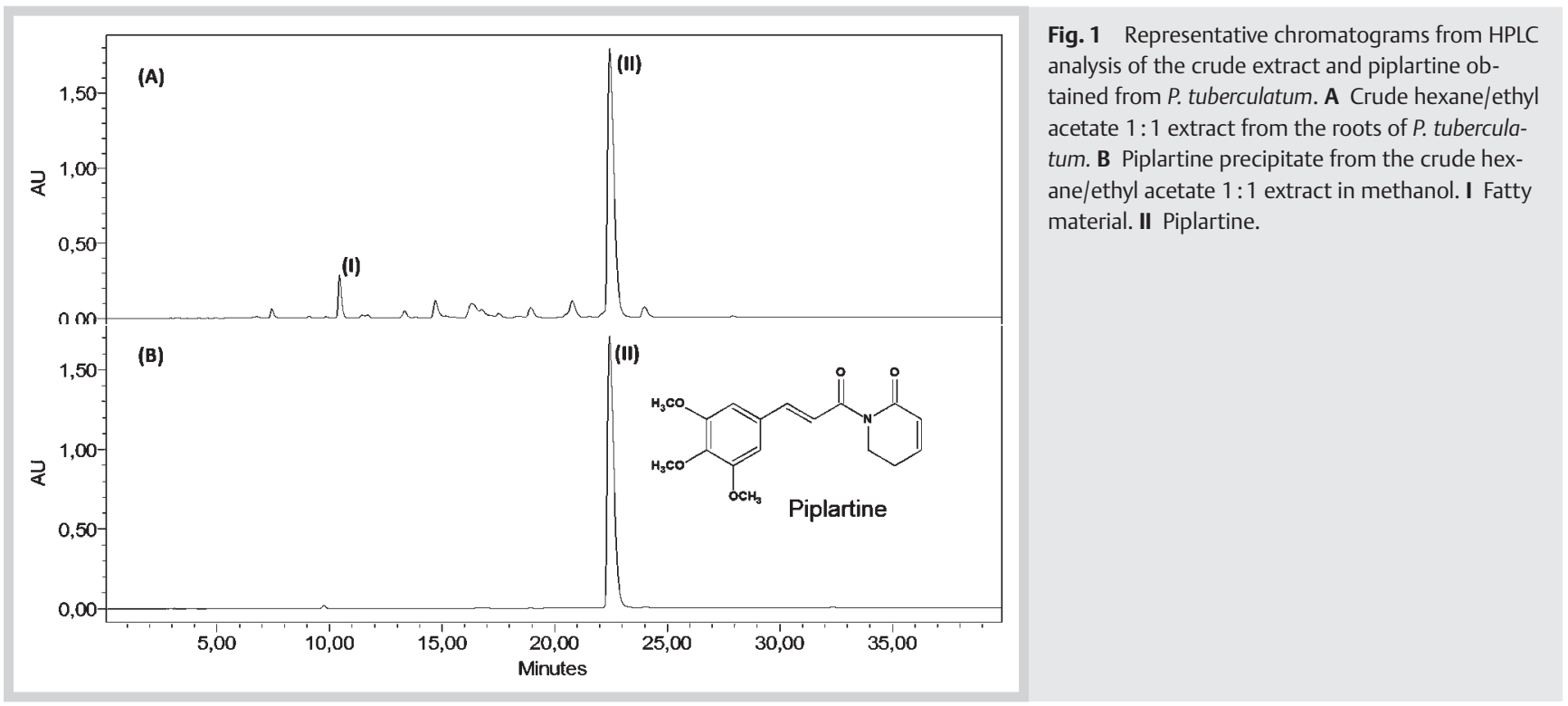

\begin{tabular}{lllll} 
Cell lines & Histotype & $\mathbf{I C}_{\mathbf{5 0}}(\boldsymbol{\mu g} / \mathbf{m L})$ & & \\
& & Crude extract & Piplartine & 5-FU \\
\hline SF-295 & Glioblastoma & $>10$ & 0.8 & 0.3 \\
& & & $0.6-1.2$ & $0.2-0.4$ \\
\hline HCT-8 & Colon carcinoma & 4.3 & 0.7 & 0.2 \\
& & $2.8-6.7$ & $0.5-0.9$ & $0.2-0.3$ \\
\hline
\end{tabular}

Table 1 In vitro cytotoxic activity of the crude extract and piplartine obtained from $P$. tuberculatum roots against tumour cell lines.

Data are presented as $\mathrm{IC}_{50}$ values and their $95 \%$ confidence interval obtained by nonlinear regression from two independent experiments performed in duplicate; 5-Fluorouracil (5-FU) was used as a positive control

The in vitro cytotoxicity was evaluated for human tumour cell lines SF-295 (glioblastoma) and HCT-8 (colon carcinoma) using the MTT assay. 5-Fluorouracil (5-FU) was used as a positive control. Table 1 summarises the half maximal inhibitory concentration $\left(\mathrm{IC}_{50}\right)$ data for cytotoxic activity. The $\mathrm{IC}_{50}$ values were $>10$ and $4.3 \mu \mathrm{g} / \mathrm{mL}$ for the crude extract obtained in SF-295 and HCT- 8 cell lines, respectively, and 0.8 and $0.7 \mu \mathrm{g} / \mathrm{mL}$ for piplartine obtained in the same cell lines, respectively. 5-FU, used as a positive control, showed IC $_{50}$ values of 0.3 and $0.2 \mu \mathrm{g} / \mathrm{mL}$ obtained in SF-295 and HCT-8 cell lines, respectively.

According to the preclinical anticancer drug-screening program used in this study, a crude extract that presents $\mathrm{IC}_{50}$ values below $30 \mu \mathrm{g} / \mathrm{mL}$ and a lead compound that presents $\mathrm{IC}_{50}$ values below $4 \mu \mathrm{g} / \mathrm{mL}$ in tumour cell line-based assays are considered promising for anticancer drug development [19]. Therefore, the cytotoxic activity observed for the crude extract and piplartine obtained from $P$. tuberculatum is considered promising.

In a second set of experiments, the in vivo HFA was used to assess the antitumour efficacy of the drugs. With this aim, tumour cells (i.e., SF-295 and HCT-8) were cultivated within biocompatible, semipermeable polyvinylidine fluoride (PVDF) hollow fibers subcutaneously implanted in the dorsal part of BALB/C nude mice. The crude extract and piplartine obtained from $P$. tuberculatum and 5-FU, used as a positive control, were administered intraperitoneally during four consecutive days. On day five, the fibers were removed to quantify cell proliferation. As shown in - Table 2, the crude extract reduced cell proliferation of tumour cells SF-295 (40.3 and 54.8\%) and HCT-8 (24.6 and 42.4\%) at doses of 100 and $200 \mathrm{mg} / \mathrm{kg} /$ day, respectively, and piplartine re- duced cell proliferation of tumour cells SF-295 (62.2 and 61.5\%) and HCT-8 (33.7 and 50.8\%) at doses of 50 and $100 \mathrm{mg} / \mathrm{kg} /$ day, respectively. In addition, 5-FU reduced cell proliferation of tumour cells SF-295 (53.7\%) and HCT-8 (70.0\%) at doses of $20 \mathrm{mg} / \mathrm{kg} /$ day. In the Piper genus, the extract of Piper capense displayed cytotoxicty against leukaemia CCRF-CEM, CEM/ADR5000, and MDAMB-231 cell lines. In addition, it induced apoptosis in CCRF-CEM cells via the alteration loss of the mitochondrial membrane potential and enhanced the production of reactive oxygen species [20]. In a screening of Venezuelan medicinal plant extracts for anticancer activity, the extracts of Piper san-vicentense and Piper arboretum showed the most cytotoxic and cytostatic activity, respectively [21]. Moreover, the extracts of Piper imperiale exhibited concentration-dependent cytotoxic effects against MCF-7 cancer cells [22]. The extract of the plant Piper longum showed potent immunomodulatory and antitumour activity, as demonstrated by different in vitro and in vivo animal models [23]. Herein, the crude extract and piplartine obtained from $P$. tuberculatum showed interesting in vitro and in vivo anticancer activity. Moreover, piplartine is a known cytotoxic agent. Its molecular pathway includes induction of oxidative stress selectively in cancer cells by the inhibition of GSTp1 and CRB1. Piplartine can be used to induce genotoxicity as an alternative strategy to killing tumour cells. In addition, piplartine has excellent oral bioavailability and inhibits tumour growth in animal models. This compound also demonstrated weak systemic toxicity that makes it suitable as a novel antineoplastic agent $[10-12,17]$.

The hollow fibers were quite well tolerated by the animals, and no signals of rejection were detected. The treatments with the 
Table 2 Antitumour efficacy of the crude extract and piplartine obtained from P. tuberculatum roots assessed by the in vivo hollow fiber assay.

\begin{tabular}{|c|c|c|c|c|c|c|}
\hline \multirow[t]{2}{*}{ Treatment } & \multirow[t]{2}{*}{ Dose (mg/kg/day) } & \multirow[t]{2}{*}{ Survival } & \multicolumn{2}{|c|}{ Proliferation (OD $595 \mathrm{~nm}$ ) } & \multicolumn{2}{|c|}{ Inhibition (\%) } \\
\hline & & & SF-295 & НСТ-8 & SF-295 & HCT-8 \\
\hline $5 \%$ DMSO & - & $6 / 6$ & $0.86 \pm 0.13$ & $1.12 \pm 0.11$ & - & - \\
\hline 5-FU & 20 & $6 / 6$ & $0.40 \pm 0.05^{*}$ & $0.33 \pm 0.09 *$ & 53.7 & 70.0 \\
\hline \multirow[t]{2}{*}{ Crude extract } & 100 & $6 / 6$ & $0.51 \pm 0.10^{*}$ & $0.84 \pm 0.14$ & 40.3 & 24.6 \\
\hline & 200 & $6 / 6$ & $0.39 \pm 0.03^{*}$ & $0.64 \pm 0.06^{*}$ & 54.8 & 42.4 \\
\hline \multirow[t]{2}{*}{ Piplartine } & 50 & $5 / 5$ & $0.32 \pm 0.04^{*}$ & $0.74 \pm 0.13$ & 62.2 & 33.7 \\
\hline & 100 & $5 / 5$ & $0.33 \pm 0.06^{*}$ & $0.55 \pm 0.05^{*}$ & 61.5 & 50.8 \\
\hline
\end{tabular}

Data are presented as mean \pm SEM for 5-6 animals; Starting one day after hollow fiber implantation, the animals were treated for four consecutive days via the intraperitoneal route; The negative control was treated with the vehicle used for diluting the test substance ( $5 \%$ DMSO). 5 -Fluorouracil ( 5 -FU) was used as a positive control; ${ }^{*} \mathrm{p}<0.05$ compared with the $5 \%$ DMSO group by ANOVA followed by Student-Newman-Keuls

crude extract and piplartine obtained from P. tuberculatum and 5-FU did not affect the conditions of the mice beyond acceptable limits, and no deaths were noticed. No significant changes in body weight were seen in the crude extract- or piplartine-treated groups. Moreover, in order to evaluate the toxicological aspects related to drug treatment, histological analyses of the liver, kidneys, heart, lungs, and spleen of the treated animals were performed; however, the treatments with the crude extract and piplartine obtained from $P$. tuberculatum did not affect the morphology of the analysed organs.

In conclusion, the crude extract and piplartine obtained from $P$. tuberculatum displayed in vitro and in vivo anticancer efficacy. The data presented here reinforce the anticancer potential of the genus Piper.

\section{Materials and Methods \\ $\nabla$ \\ Cells}

Cytotoxicity and antitumour assays were determined in human tumour cells, namely, SF-295 (glioblastoma) and HCT-8 (colon carcinoma), donated by Children's Mercy Hospital, Kansas City, MO, USA. Cells were maintained in RPMI-1640 medium (GibcoBRL) supplemented with $10 \%$ FBS (Cultilab) and $2 \mathrm{mM}$ L-glutamine (Vetec Química Fina). Cells were harvested by treatment with $0.25 \%$ trypsin EDTA solution (Gibco-BRL). All cell lines were cultured in cell culture flasks at $37^{\circ} \mathrm{C}$ in a $5 \% \mathrm{CO}_{2}$ atmosphere and subcultured every 3-4 days to maintain exponential growth. Cytotoxicity and antitumour experiments were conducted with cells in the exponential growth phase.

\section{Animals}

A total of 34 female BALB/c nude (nu/nu) mice, aged 6-8 weeks, were obtained from the animal facilities of the State University of São Paulo, Faculty of Medicine, São Paulo, Brazil. They were kept in well-ventilated, sterile cages (Alesco) under standard conditions of light (12 h with alternate day and night cycles) and temperature $\left(22 \pm 1^{\circ} \mathrm{C}\right)$, and were housed with access to a commercial sterile rodent stock diet (Nutrilabor) and water ad libitum. The animals were treated according to the ethical principles for animal experimentation of the SBCAL (Brazilian Association of Laboratory Animal Science), Brazil, and the study was approved by the local Ethical Committee on Animal Research (\# 102/2007).

\section{Plant material}

Roots of P. tuberculatum were collected at Campus do Pici of the Universidade Federal do Ceará, Fortaleza, Ceará State, Northeastern Brazil, in January 2014. The identification was performed by E.R. Silveira, after comparison with the voucher specimen EAC 34736 deposited at the Prisco Bezerra Herbarium, Departamento de Biologia, Universidade Federal do Ceará.

Preparation of the crude extract and piplartine isolation The dried powdered roots (331.0 g) of P. tuberculatum were macerated with a mixture of hexane/ethyl acetate $1: 1(1 \times 2.0 \mathrm{~L}$ and $2 \times 1.3 \mathrm{~L}$ ). After filtration, the solutions were pooled together and evaporated under reduced pressure to yield a yellowish solid crude extract (3.47 g). The crude extract ( $2.58 \mathrm{~g}$ ) was suspended in $\mathrm{MeOH}$ to yield $895.2 \mathrm{mg}$ of a precipitate and $1.44 \mathrm{~g}$ of the mother liquors. The precipitate was recrystallised from methanol to yield piplartine (purity $>99 \%$ ).

The chromatographic analysis was carried out using a Waters 1525 (Milford) chromatograph, equipped with a binary pump and a photodiode-array detector (Waters-2996 PDA). A gradient elution mode, using hexane-ethyl acetate, varying from $20 \%$ to $100 \%$ ethyl acetate, over a 40 -min total running time, was accomplished through a Phenomenex silica column $(250 \times 4.6 \mathrm{~mm})$ using an injection volume of $50 \mu \mathrm{L}$ at a flow rate of $1.0 \mathrm{~mL} / \mathrm{min}$, while observing at $275 \mathrm{~nm}$.

\section{In vitro cytotoxic activity assay}

Tumour cell growth was determined by the ability of living cells to reduce the yellow dye MTT to a purple formazan product, as described by Mosmann [24]. For all experiments, cells were seeded in 96 -well plates $\left(0.7 \times 10^{5}\right.$ cells $/ \mathrm{mL}$ in $100 \mu \mathrm{L}$ of medium $)$. After $24 \mathrm{~h}$, the drugs $(0.039$ to $10 \mu \mathrm{g} / \mathrm{mL})$ were dissolved in pure DMSO and added to each well using high-throughput screening (HTS; Biomek 3000, Beckman Coulter, Inc.). Then, the cells were incubated for 72 h. 5-FU (purity > 99\%; Sigma Chemical Co.) was used as a positive control. At the end of incubation, the plates were centrifuged and the medium was replaced by fresh medium $(150 \mu \mathrm{L})$ containing $0.5 \mathrm{mg} / \mathrm{mL}$ MTT. Three hours later, the formazan product was dissolved in $150 \mu \mathrm{L}$ DMSO and absorbance was measured using a multiplate reader (DTX 880 Multimode Detector, Beckman Coulter, Inc.). The drug effects are expressed as the percentage of control absorbance of reduced dye at $595 \mathrm{~nm}$. 


\section{In vivo hollow fiber assay}

The in vivo HFA was performed as previously described by Hollingshead et al. [18] with minor modifications. PVDF hollow fibers with a $1-\mathrm{mm}$ internal diameter and a molecular weight cutoff point of $500 \mathrm{kDa}$ were used (Spectrum Laboratories). The fibers were cut into $12-15 \mathrm{~cm}$ long pieces, washed $2 \times$ with sterile distilled water, and were then kept in sterile conditions.

Before use, under sterile conditions, the fibers were incubated in complete RPMI with $20 \%$ FBS overnight (packaging time). Cell viability was assessed by the trypan blue exclusion assay. A cell suspension of $1 \times 10^{7}$ cell $/ \mathrm{mL}$ (equivalent to 200000 cells $/ 20 \mu \mathrm{L} / 2 \mathrm{~cm}$ PVDF fiber) at $4^{\circ} \mathrm{C}$ was injected into the fiber, with the ends thereof immediately heat-sealed. The fibers were cut into $2 \mathrm{~cm}$ each, transferred to petri plates, and incubated in complete RPMI medium for $24 \mathrm{~h}$ prior to implantation in the mice. Each cell was injected into one fiber of a different color (HCT-8, yellow fibers; SF-295, blue fibers).

Before implantation, the mice were anaesthetised with ketamine (90 mg/kg)-xylazine ( $4.5 \mathrm{mg} / \mathrm{kg}$ ). A small incision in the neck was made to permit subcutaneous (s.c.) implantation of the fibers in the dorsal part of the animal. Each animal received two fibers at the s.c. site. All incisions were sealed with a surgical stapler. The treatments were started one day after hollow fiber implantation. At the beginning of the experiment, the mice were divided into six groups, as follows: group 1 - negative control (5\% DMSO, $\mathrm{n}=6$ ); group 2 - positive control (5-FU, $20 \mathrm{mg} / \mathrm{kg} /$ day, $\mathrm{n}=6$ ); group 3 - crude extract ( $200 \mathrm{mg} / \mathrm{kg} / \mathrm{day}, \mathrm{n}=6$ ); group 4 - crude extract $(100 \mathrm{mg} / \mathrm{kg} / \mathrm{day}, \mathrm{n}=6)$; group 5 - piplartine $(100 \mathrm{mg} / \mathrm{kg} /$ day, $\mathrm{n}=5$ ); group 6 - piplartine ( $50 \mathrm{mg} / \mathrm{kg} / \mathrm{day}, \mathrm{n}=5)$. The dosages were determined based on previous articles $[11,12]$. The test compounds were administered intraperitoneally during four consecutive days. On day five, the fibers were removed to quantify the antiproliferative capacity.

Tumour cell proliferation was quantified through the MTT assay. For this purpose, the fibers removed from the animals were incubated with $1 \mathrm{mg} / \mathrm{mL}$ MTT in 6-well plates during $4 \mathrm{~h}$ at $37^{\circ} \mathrm{C}$ and $5 \% \mathrm{CO}_{2}$. The MTT solution was aspirated and the fibers were washed with saline solution containing protamine sulphate $2.5 \%$ and incubated in protamine solution overnight at $4{ }^{\circ} \mathrm{C}$. The fibers were transferred to 24-well plates, cut into 2 or 3 pieces, and put to dry. The formazan was dissolved in $500 \mathrm{~mL}$ DMSO, the aliquots $(150 \mathrm{uL})$ were transferred to 96 -well plates, and absorbance was measured at $595 \mathrm{~nm}$ (DTX-880, Beckman Coulter). The drug effect was quantified as the percentage of control absorbance.

After the treatment described above, the liver, kidneys, heart, lungs, and spleen were excised and fixed in $10 \%$ formaldehyde. After fixation with formaldehyde, the organs were submitted to a gross examination for size or colour changes and haemorrhage. Portions were then cut into small pieces, followed by staining of the histological sections with haematoxylin and eosin. Histological analysis was performed by light microscopy. The presence and extent of liver, kidneys, heart, lungs, and spleen lesions attributed to the drugs were considered.

\section{Statistical analysis}

Data are presented as mean \pm SEM or $\mathrm{IC}_{50}$ values and their $95 \%$ confidence intervals (CI 95\%) were obtained by nonlinear regression. The differences between experimental groups were compared by ANOVA (analysis of variance) followed by the StudentNewman-Keuls test $(\mathrm{p}<0.05)$. All statistical analyses were performed using the GraphPad program (Intuitive Software for Science).

\section{Acknowledgements}

$\nabla$

This work was financially supported by the Brazilian agencies Capes (Coordenadoria de Apoio a Pesquisa e Ensino Superior), CNPq (Conselho Nacional de Desenvolvimento Cientifico e Tecnológico), and FUNCAP (Fundação Cearense de Apoio ao Desenvolvimento Científico e Tecnológico).

\section{Conflict of Interest}

$\nabla$

The authors have declared that there is no conflict of interest.

\section{Affiliations}

${ }^{1}$ Centro de Pesquisas Gonçalo Moniz, Fundação Oswaldo Cruz, Salvador, Bahia, Brazil

2 Departamento de Biofísica e Fisiologia/Programa de Pós-Graduação em Ciências Farmacêuticas, Universidade Federal do Piauí, Teresina, Piauí, Brazil ${ }^{3}$ Departamento de Radiologia, Faculdade de Medicina, Universidade de São Paulo, São Paulo, Brazil

${ }^{4}$ Departamento de Química Orgânica, Universidade Federal do Ceará, Fortaleza, Ceará, Brazil

${ }^{5}$ Departamento de Fisiologia e Farmacologia, Faculdade de Medicina, Universidade Federal do Ceará, Fortaleza, Ceará, Brazil

${ }^{6}$ Fundação Oswaldo Cruz, Fortaleza, Ceará, Brazil

\section{References}

1 Chaves MC, Júnior AGF, Santos BVO. Amides from Piper tuberculatum fruits. Fitoterapia 2003; 74: 181-183

2 Felipe FCB, Sousa-Filho JT, Souza LEO, Silveira JA, Uchoa DEA, Silveira ER, Pessoa ODL, Viana GSB. Piplartine, an amide alkaloid from Piper tuberculatum, presents anxiolytic and antidepressant effects in mice. Phytomedicine 2007; 14: 605-612

3 Lavor PL, Santiago GM, Gois RW, Sousa LM, Bezerra GP, Romero NR, Arriaga AM, Lemos $T L$, Alves $P B$, Gomes $P C$. Larvicidal activity against Aedes aegypti of essential oils from northeast Brazil. Nat Prod Commun 2012; 7: 1391-1392

4 Rapado LN, Pinheiro AS, Lopes PO, Fokoue HH, Scotti MT, Marques JV, Ohlweiler FP, Borrely SI, Pereira CA, Kato MJ, Nakano E, Yamaguchi LF. Schistosomiasis control using piplartine against Biomphalaria glabrata at different developmental stages. PLoS Negl Trop Dis 2013; 7: e2251

5 Burci LM, Pereira IT, Silva LM, Rodrigues RV, Facundo VA, Militão JS, Santos AR, Marques MC, Baggio CH, Werner MF. Antiulcer and gastric antisecretory effects of dichloromethane fraction and piplartine obtained from fruits of Piper tuberculatum Jacq. in rats. J Ethnopharmacol 2013; 148: 165-174

6 Bezerra DP, Pessoa C, Moraes MO, Silveira ER, Lima MA, Elmiro FJ, CostaLotufo $L V$. Antiproliferative effects of two amides, piperine and piplartine, from Piper species. Z Naturforsch C 2005; 60: 539-543

7 Bezerra DP, Pessoa C, Moraes MO, Costa-Lotufo LV, Gouvea DR, Jabor VAP, Lopes NP, Borges KB, Lima MAS, Silveira ER. Sensitive method for determination of piplartine, an alkaloid amide from Piper species, in rat plasma samples by liquid chromatography-tandem mass spectrometry. Quím Nova 2011; 35: 460-465

8 Bezerra DP, Militão GC, Castro FO, Pessoa C, Moraes MO, Silveira ER, Lima MA, Elmiro FJ, Costa-Lotufo LV. Piplartine induces inhibition of leukemia cell proliferation triggering both apoptosis and necrosis pathways. Toxicol In Vitro 2007; 21: 1-8

9 Jyothi D, Vanathi P, Gowri PM, Rao VRS, Rao JM, Sreedhar AS. Diferuloylmethane augments the cytotoxic effects of piplartine isolated from Piper chaba. Toxicol In Vitro 2009; 23: 1085-1091

10 Raj L, Ide T, Gurkar AU, Foley M, Schenone M, Li X, Tolliday NJ, Golub TR, Carr SA, Shamji AF, Stern AM, Mandinova A, Schreiber SL, Lee SW. Selective killing of cancer cells by a small molecule targeting the stress response to ROS. Nature 2011; 475: 231-234

11 Bezerra DP, Castro FO, Alves AP, Pessoa C, Moraes MO, Silveira ER, Lima MA, Elmiro FJ, Costa-Lotufo LV. In vivo growth-inhibition of Sarcoma 180 by piplartine and piperine, two alkaloid amides from Piper. Braz J Med Biol Res 2006; 39: 801-807

12 Bezerra DP, Castro FO, Alves AP, Pessoa C, Moraes MO, Silveira ER, Lima MA, Elmiro FJ, de Alencar NM, Mesquita RO, Lima MW, Costa-Lotufo LV. In vitro and in vivo antitumor effect of 5-FU combined with piplartine and piperine. J Appl Toxicol 2008; 28: 156-163 
13 Bezerra DP, Moura DJ, Rosa RM, Vasconcellos MC, Silva AC, Moraes MO, Silveira ER, Lima MA, Henriques JA, Costa-Lotufo LV, Saffi J. Evaluation of the genotoxicity of piplartine, an alkamide of Piper tuberculatum, in yeast and mammalian V79 cells. Mutation Res 2008; 652: 164-174

14 Bezerra DP, Vasconcellos MC, Machado MS, Villela IV, Rosa RM, Moura DJ, Pessoa C, Moraes MO, Silveira ER, Lima MA, Aquino NC, Henriques JA, Saffi J, Costa-Lotufo LV. Piplartine induces genotoxicity in eukaryotic but not in prokaryotic model systems. Mutation Res 2009; 677: 8-13

15 Bodiwala HS, Singh G, Singh R, Dey CS, Sharma SS, Bhutani KK, Singh IP. Antileishmanial amides and lignans from Piper cubeba and Piper retrofractum. J Nat Med 2007; 61: 418-421

16 Cotinguiba F, Regasini LO, Bolzani VS, Debonsi HM, Passerini GD, Cicarelli $R M B$, Kato MJ, Furlan M. Piperamides and their derivatives as potential anti-trypanosomal agents. Med Chem Res 2009; 18: 703-711

17 Bezerra DP, Pessoa C, Moraes MO, Saker-Neto N, Silveira ER, Costa-Lotufo $L V$. Overview of the therapeutic potential of piplartine (piperlongumine). Eur J Pharm Sci 2013; 48: 453-463

18 Hollingshead MG, Alley MC, Camalier RF, Abbott BJ, Mayo JG, Malspeis L, Grever MR. In vivo cultivation of tumor cells in hollow fibers. Life Sci 1995; 57: 131-141
19 Suffness M, Pezzuto JM. Assays related to cancer drug discovery. In: Hostettmann K, editor. Methods in plant biochemistry: assays for bioactivity. London: Academic Press; 1990: 71-133

20 Kuete V, Sandjo LP, Wiench B, Efferth T. Cytotoxicity and modes of action of four Cameroonian dietary spices ethno-medically used to treat cancers: Echinops giganteus, Xylopia aethiopica, Imperata cylindrica and Piper capense. J Ethnopharmacol 2013; 149: 245-253

21 Taylor P, Arsenak M, Abad MJ, Fernández A, Milano B, Gonto R, Ruiz MC, Fraile S, Taylor S, Estrada O, Michelangeli F. Screening of Venezuelan medicinal plant extracts for cytostatic and cytotoxic activity against tumor cell lines. Phytother Res 2013; 27: 530-539

22 Diaz LE, Munoz DR, Prieto RE, Cuervo SA, Gonzalez DL, Guzman JD, Bhakta S. Antioxidant, antitubercular and cytotoxic activities of Piper imperiale. Molecules 2012; 17: 4142-4157

23 Sunila ES, Kuttan G. Immunomodulatory and antitumor activity of Piper longum Linn. and piperine. J Ethnopharmacol 2004; 90: 339-346

24 Mosmann T. Rapid colorimetric assay for cellular growth and survival: application to proliferation and cytotoxicity assays. J Immunol Methods 1983; 16: 55-63 